\title{
Statyba
}

\section{THE EVALUATION OF A COMPANY'S STRATEGY BY THE ANSOFF'S PRODUCT MARKET MATRIX}

\section{R. Ginevičius \& R. Auškalnytè}

To cite this article: R. Ginevičius \& R. Auškalnytè (2001) THE EVALUATION OF A COMPANY'S STRATEGY BY THE ANSOFF'S PRODUCT MARKET MATRIX, Statyba, 7:2, 158-165, DOI:

10.1080/13921525.2001.10531717

To link to this article: https://doi.org/10.1080/13921525.2001.10531717

曲 Published online: 30 Jul 2012.

Submit your article to this journal

Џll Article views: 1667

4 Citing articles: 1 View citing articles 진 


\title{
IMONĖS STRATEGIJOS VERTINIMAS PAGAL I. ANSOFFO PRODUKTO-RINKOS MODELI
}

\author{
R. Ginevičius, R. Auškalnytẻ \\ Vilniaus Gedimino technikos universitetas
}

\section{Ivadas}

Mūsų dienų ekonomikai būdinga stiprẻjanti konkurencija. Imonès, siekdamos igyti konkurencini pranašuma, turi rūpintis savo veiklos efektyvumo didinimu, tinkamiau naudoti turimą potencialą. Plačiaja prasme konkurencinis pranašumas suprantamas kaip įmonès gebèjimas sukurti didesnę vertę ir gauti didesni pelną nei vidutinis konkurentų. Konkurencinio pranašumo išlaikymas tampa problemiškas, nes greitai kinta paklausa, didejja konkuruojančių imonių skaičius, rinkai pateikiamos inovacijos, greitai keičiasi technologijos ir pan.

Todèl neatsitiktinai versle vis didesnę reikšmę igyja strategija. Ši sąvoka verslo vadybos terminologijoje atsirado senokai, tačiau ji interpretuojama gana plačiai. Strategiją autoriai supranta skirtingai: konkurencijos valdymas; kompanijos skirtingų veiklų suderinimas; kompanijos padèties nustatymas ir valdymas, siekiant efektyvumo; konfliktų valdymas ir pan.

Nors pastaraisiais metais strategija tapo vienu iš populiariausių tyrimų objektu, negalima teigti, kad yra bendras ir universalus pagristas strategijos apibrèžimas, teorija ar visiems priimtina strategijos koncepcija. Dauguma autorių koncentruojasi ties strategijos formulavimo procesu, kartais užmiršdami, kur jis veda [1]. Mūsu manymu, derètu atkreipti dėmesi i I. Ansoffo teorinius darbus, kadangi juose išskirta aiški riba tarp strategijos formulavimo proceso ir strategijos, kaip šio proceso rezultato. Be to, šie darbai reikšmingi ir tuo, kad: 1) paskutiniame šio amžaus dešimtmetyje i̇moniu pertvarka tapo dominuojančiu verslo praktikos strateginiu sprendimu visame pasaulyje; 2) itin daug demesio skiriama verslui atgaivinti, o ypač jo naujovėms ir augimui.

Šiame darbe, remiantis I. Ansoffo požiūriu bei jo pasiūlytu produkto-rinkos modeliu, bandoma pasiūlyti, kaip nustatyti imonei tikslingą strategiją.

\section{I. Ansoffo produkto-rinkos strateginis modelis}

Svarbiausia Ansoffo koncepcijos idejja yra ta, kad organizacija, norinti sèkmingai veikti, turi būti adaptyvi besikeičiančiomis veiklos sąlygomis. Be to, imonei reikia aiškiai apibūdintos veiklos kompetencijos ir plètros krypties.

Atsižvelgdamas $i$ organizacijos plètrą, I. Ansoffas savo modelyje išskyrè keturis jos veiklos strategijos tipus: 1) skverbimassi i rinką, 2) produkto tobulinima, 3) rinkos plètrą ir 4) diversifikaciją [2]. Skverbimosi i rinka, produkto tobulinimo ir rinkos pletros strategijos sujungtos ir pavadintos ekspansijos strategija (1 pav.).

Skverbimasis i rinką - tai tokia veiklos kryptis, kai organizacija siekia išplèsti pardavimu apimtis, nenukrypdama nuo pradinès produkto-rinkos strategijos. Tam tikrais veiksmais didinama esamų produktų pardavimų apimtis arba ieškoma naujų klientu. Skverbimosi i rinką strategija realizuojama jvariais marketingo veiksmais didinant produkto vartojimą, produktyvumą ar gerinant produkto kokybę. Strateginis imonès siekis igyti konkurencini pranašumą bei augimą rinkoje gali būti pasiektas ir mažinant gamybos išlaidas, t. y. mažinant išlaidas ir keliant gamybos efektyvumą. Mažos žaliavų kainos leidžia ịmonei igyti konkurencini pranašumą, o kai kuriose šakose šis pranašumas gali būti igytas mažinant darbo išlaidas. Be to, darbo kaip ir žaliavu išlaidos formuoja esmines bendru gamybos išlaidų proporcijas. Todèl išlaidos bei jų plètra laikui bègant lemia skirtumus tarp imoniu ir gali būti vienu iš konkurencingumo komponentu.

Rinkos plètra iliustruoja augimą, kai organizacija siekia pritaikyti esamus arba iš dalies modifikuotus produktus naujai rinkai ir, išlaikydama gamybos pastovumą, igyti pranašumą rinkoje $[3,1]$. Pasirinkusi rinkos plètros strategija, organizacija nukreipia esamus produktus $\mathfrak{i}$ naujas rinkos sritis. Rinkos plètrą realizuoti gali- 


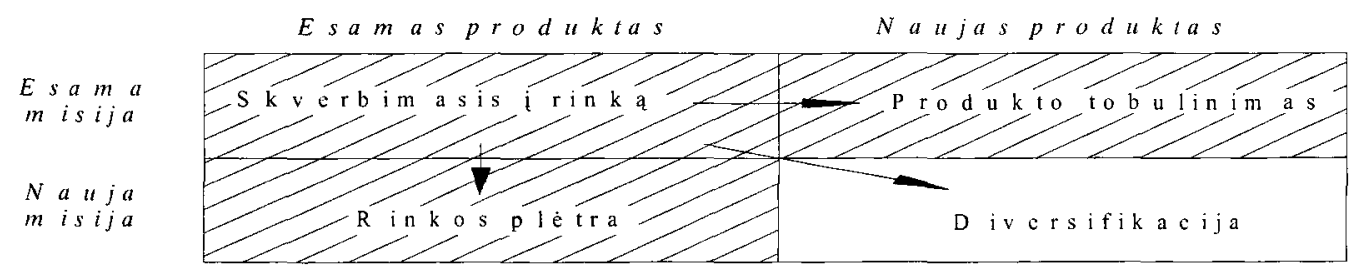

1 pav. Ansoffo produkto-rinkos strateginis modelis

Fig 1. Ansoff's product-market matrix

ma užimant naujus rinkos segmentus, siūlant naują produktą ar skverbiantis i naujas geografines sritis.

Produkto tobulinimo atveju sukuriamas naujas produktas, kuris pakeis esamą. Produkto tobulinimo, kaip skverbimosi i rinka, strategija leidžia imonei plèstis bei išlikti rinkoje. Ši strategija gali būti realizuota mažinant išlaidas, tobulinant ar kuriant naujus produktus.

Produkto tobulinimas yra siejamas su produkto savybiu, kokybès, dizaino pakeitimais, didesnès produktu ivairovès pateikimu rinkai, t. y. siekiant būti pranašiems už konkurentus.

Naujų produktų kūrimas yra susijęs su lyderiavimu mokslo ir technineje veikloje. D. Chano nuomone [4], produkto tobulinimo strategija pasirinkusi imonè plètoja veikla, susijusią su tyrimais ir projektavimu. Todèl ši pasirinkimą geriausiai atspindi organizacijos skiriamos léšos tyrimams ir projektavimui. Tai ne tik strateginis sprendimas, kuris, be kita ko, išreiškia imonès vadovu vertybiu sistema, bet ir organizacijos investicija $i$ ateiti, o jụ santykis su pardavimų apimtimi atspindi organizacijos augimą. Alternatyva šiai veiklai gali būti licenciju isigijimas arba specialistu pritraukimas.

Diversifikacija Ansoffo modelyje išreiškia toki augima, kai rinka ir produktas yra visiškai nauji.

Diversifikacijos strategijos pasirinkimą lemia:

1) imonès tikslụ ir produkto-rinkos modelio, apibrèžto ekspansija, neatitikimas;

2) atsiradęs didesnis grynujų pinigų kiekis, viršijantis ekspansijos poreikius;

3) galimybès gauti didesni pelną pasirinkus diversifikaciją;

4) turima informacija, leidžianti palyginti ekspansijos ir diversifikacijos strategijas.

Kadangi tai didžiausios rizikos būdas, labiausiai atitraukiantis imonę nuo jos gamybos ir marketingo, šiame darbe bus vertinamos ekspansijos strategijos.

\section{Kriterijų, ivertinančiụ ekspansijos strategijas, nu- statymas}

Pirmuoju tyrimų etapu pasirenkami i̇monès $X$ ekspansijos strategijas ivertinantys kriterijai, apskaičiuojama jų kitimo dinamika:

$$
I_{j}=\frac{I^{p a}}{I^{p}},
$$

čia $I_{j}$ - atitinkamos ekspansijos strategijos pokyčio rodiklis; $I^{p}$ - atitinkamo ekspansijos strategijos kriterijaus reikšmė analizuojamo periodo pradžioje; $I^{p a}-$ atitinkamo ekspansijos strategijos kriterijaus reikšmè analizuojamo periodo pabaigoje.

Skaičiuojamas kiekvienos iš ekspansijos strategiju apibendrinantis rodiklis:

$$
\sqrt[n]{\prod_{j=1}^{n} I_{j}}
$$

Vertinant ekspansijos strategijas pasirinkti šie kriterijai:

a) skverbimosi i rinką strategijai:

- darbo išlaidos,

- išlaidos žaliavoms,

- darbo našumas,

- papildomos išlaidos vietos rinkoms isisavinti;

b) produkto tobulinimo strategijai:

- naujų produktų skaičius,

- išlaidos projektavimui ir tyrimams,

- specialistų, dirbančių tyrimų ir projektavimo srityje, skaičius,

- parduotu licenciju skaičius,

- isigytu licencijų skaičius;

c) rinkos plètros strategijai:

- naujų geografinių rinkų skaičius,

- papildomos išlaidos naujoms geografinèms rinkoms isisavinti, 
- darbuotojų, dirbančių naujose geografinèse rinkose, skaičius.

Antruoju tyrimų etapu kriterijus apibūdinantys skaičiai suvedami i matricas (1 lentelè).

1 lentelè. Produktų klasifikacijos schema

Table 1. Classification scheme of products

\begin{tabular}{|l|c|c|c|c|}
\hline \multirow{4}{*}{ Produkto tipas } & \multirow{4}{*}{ Grupe } & \multicolumn{3}{|c|}{$\begin{array}{c}\text { Ekspansijos strategiju } \\
\text { apibendrintu rodikliu } \\
\text { vertinimas }\end{array}$} \\
\cline { 2 - 5 } & & $I_{k}$ & $I_{t}$ & $I_{r p l}$ \\
\hline \multirow{4}{*}{$\begin{array}{l}\text { Plataus } \\
\text { vartojimo } \\
\text { produktai }\end{array}$} & $\mathrm{PT}_{1}$ & $\mathrm{x}_{11}$ & $\mathrm{x}_{12}$ & $\mathrm{x}_{13}$ \\
\cline { 2 - 5 } & $\mathrm{PT}_{2}$ & $\mathrm{x}_{21}$ & $\mathrm{x}_{22}$ & $\mathrm{x}_{23}$ \\
\cline { 2 - 5 } & $\mathrm{PT}_{3}$ & $\mathrm{x}_{31}$ & $\mathrm{x}_{32}$ & $\mathrm{x}_{33}$ \\
\cline { 2 - 5 } & $\cdots$ & $\cdots$ & $\cdots$ & $\ldots$ \\
\hline \multirow{4}{*}{$\begin{array}{l}\text { Gamybines- } \\
\text { technines } \\
\text { paskirties } \\
\text { produktai }\end{array}$} & $\mathrm{PT}_{\mathrm{n}}$ & $\mathrm{x}_{\mathrm{n} 1}$ & $\mathrm{x}_{\mathrm{n} 2}$ & $\mathrm{x}_{\mathrm{n} 3}$ \\
\cline { 2 - 5 } & $\mathrm{PT}_{1}$ & $\mathrm{x}_{11}$ & $\mathrm{x}_{12}$ & $\mathrm{x}_{13}$ \\
\cline { 2 - 5 } & $\mathrm{PT}_{2}$ & $\mathrm{x}_{21}$ & $\mathrm{x}_{22}$ & $\mathrm{x}_{23}$ \\
\cline { 2 - 5 } & $\mathrm{PT}_{3}$ & $\mathrm{x}_{31}$ & $\mathrm{x}_{32}$ & $\mathrm{x}_{33}$ \\
\cline { 2 - 5 } & $\cdots$ & $\cdots$ & $\cdots$ & $\ldots$ \\
\cline { 2 - 5 } & $\mathrm{PT}_{\mathrm{n}}$ & $\mathrm{x}_{\mathrm{n} 1}$ & $\mathrm{x}_{\mathrm{n} 2}$ & $\mathrm{x}_{\mathrm{n} 3}$ \\
\hline
\end{tabular}

1 lentelèje pateiktoje produktụ klasifikacijos schemoje $I_{k}$ - skverbimosi i rinką apibendrintas rodiklis; $I_{t} \rightarrow$ produktu tobulinimo strategijos apibendrintas rodiklis; $I_{r p l}$ - rinkos plètros strategijos apibendrintas rodiklis. Remiantis 1 lentele sudaroma apibendrinta matrica (2 lentelè).

2 lentelè. Produkto klasifikacijos apibendrinta matrica

Table 2. Generalized matrix of product classification

\begin{tabular}{|c|c|c|c|}
\hline $\mathrm{PT}$ & $I_{k}$ & $I_{t}$ & $I_{r p l}$ \\
\hline$I_{k}$ & 1 & $x_{t}^{k}$ & $x_{r p l}^{k i}$ \\
\hline$I_{t}$ & $x_{t}^{k}$ & 1 & $x_{r p l}^{t}$ \\
\hline$I_{r p l}$ & $x_{k}^{r p l}$ & $x_{t}^{r p l}$ & 1 \\
\hline
\end{tabular}

Tokios matricos sudaromos kiekvienai produkto grupei. Jas turint kiekvienos produkto grupès vertinimo kriterijai dauginami iš vertinimo prioriteto ir gaunami apibendrinti produkto grupès prioritetai, pagal kuriuos nustatoma produkto grupé, turinti ịtakos įmonès strategijai.

Nustačius produkto grupę, turinčią itakos imonès strategijai, kiekviena produkto grupé priskiriama tam tikrai jo gyvavimo ciklo fazei. Tuo tikslu remsimès pardavimo apimčių rodikliu $\Delta$ ir pardavimu pokyčio užsienio rinkose rodikliu EXP.

$$
\Delta=\frac{\text { Pardavimu apimtis } t+5 \text { metais }}{\text { Pardavimy apimtis } t \text { metais }} .
$$

Jeigu produkto kasmetinès pardavimų tendencijos per paskutinius $n$ metu yra:

1) neigiamos, tai produktas yra gyvavimo ciklo kritimo etape;

2) $0-10 \%$, tai produktas yra gyvavimo ciklo brandos etape;

3) daugiau kaip 10\%, tai produktas yra gyvavimo ciklo augimo etape.

Pardavimų pokytis užsienio rinkose EXP nustatomas taip:

$$
\text { EXP }=\frac{\text { Pardavimu užsienio rinkose pokytis }}{\text { Bendros pardavimu apimties pokytis }} .
$$

Jeigu rodiklis $E X P<10 \%$, produktų pardavimas orientuotas $\mathrm{i}$ vidaus rinkas, jeigu $E X P>10 \%-\mathfrak{i}$ užsienio rinkas.

Remiantis šiais rodikliais, daroma išvada dèl produkto priskyrimo atitinkamai gyvavimo ciklo fazei.

Taip šiuo etapu atrenkamas produkto tipas, turintis itakos imonès pasirinktai ekspansijos strategijai, ir nustatomas jo gyvavimo ciklas.

\section{Imonès sugebėjimų taikyti pasirinktą strategiją kiekybinis ivertinimas}

Trečiuoju tyrimo etapu nustatomas imonès sugebèjimas taikyti tikslingą strategiją. Remsimès produkto gyvavimo ciklo koncepcija, kuri literatūroje užima svarbią vietą kaip prognozavimo instrumentas ir kaip korporacijos marketingo strategijos pagrindas [5]. Tyrimams pasirenkami inovacijų fazès etapai: produkto koncepcija, projekto studijos, bandomoji serija bei produkto rinkos fazès etapai: gimimas, augimas ir branda.

Imonès sugebèjimu taikyti pasirinktą strategiją ịvertinimas turi būti atliktas pagal atitinkamą kriterijų. Jị galima vadinti produktu atnaujinimo koeficientu $K_{0}$. Dydis $K_{0}$ charakterizuoja visų pagrindinių imonès 
padalinių darbą, turimą iranga, technologiją darbuotojus, sugebejjimą reaguoti i pokyčius rinkoje ir pan.

Koeficientą $K_{0}$ galima apskaičiuoti kaip naujo produkto inovacijų fazès ir realizavimo rinkoje laiko santyki:

$$
K_{0}=\frac{T_{i s}}{T_{r}}
$$

čia $T_{i s}$ - produkto inovacijų fazès laikas arba vidinis ¡monés lankstumo veiksnys; $T_{r}$ - gamybos ir realizavimo laikas arba išorinis lankstumo veiksnys.

Norint apskaičiuoti $K_{0}$, būtina žinoti vidutini naujo produkto ièjimo i rinką ciklą, kuri sudaro tokie etapai, kaip produkto koncepcija, projekto studijos, produkto gimimas, konstravimas, prototipas, bandomoji serija bei pardavimai. Šių etapų laiko parametrus apskaičiuosime remdamiesi koreliacine regresine analize pagal šakos konkuruojančių imonių duomenimis.

Produkto koncepcijos fazès laikas priklauso nuo žmonių, dirbančių darbus, susijusius su produkto kūri$\mathrm{mu}$, skaičiaus $m_{r}$ ir pelno dalies, tenkančios tyrimams, ir grynojo pelno santykio per metus $n_{d}$ :

$$
\begin{gathered}
t_{1}=f\left(m_{r}, n_{d}\right), \\
t_{1}=a_{01}+a_{r} m_{r}+a_{d} n_{d} .
\end{gathered}
$$

Analogiškai galima nustatyti projekto studijų laiką:

$$
\begin{gathered}
t_{2}=f\left(m_{r}^{\prime \prime}, n_{d}^{\prime \prime}\right), \\
t_{2}=a_{02}+a_{r} m_{r}^{\prime \prime}+a_{d} n_{d}^{\prime \prime} .
\end{gathered}
$$

čia $a_{01}, a_{02}, a_{r}, a_{d}$ - regresijos koeficientai.

Iejjimo i rinką laiką atitinka produkto gimimo, konstravimo ir prototipo, bandomosios serijos bei serijos, pardavimu trukmè:

$$
t_{3}=t_{31}+t_{32},
$$

čia $t_{31}$ - vidutinis produkto gimimo, konstravimo laikas, $t_{32}$ - produkto prototipo ir bandomosios serijos gamybos laikas.

Laikas $t_{31}$ - tai apsirūpinimo technine iranga galimybės. Jis priklauso nuo žmonių, dalyvaujančių rengiant technologinę iranga, skaičiaus $v_{r}$, turimos irangos skaičiaus $n_{s n 0}$ ir jos naudojimo laiko $t_{c l}$ :

$$
\begin{gathered}
t_{31}=f\left(v_{r}, n_{s n 0}, t_{c l}\right), \\
t_{31}=a_{0 m}+a_{0 m r} v_{r}+a_{0 m s n 0} n_{s n 0}+a_{0 m c l} t_{c l} .
\end{gathered}
$$

Laikas $t_{32}$ priklauso nuo žmonių, dalyvaujančių bandomosios serijos gamyboje, skaičiaus $n_{d}$, naujos ịrangos skaičiaus $n_{c n 0}$ ir jos naudojimo laiko $t_{c l}^{0}$ :

$$
t_{3_{2}}=f\left(n_{d}, n_{c n 0}, t_{c l}\right)
$$

$$
t_{3_{2}}=a_{0 n}+a_{0 n d} n_{d}+a_{0 n c n} n_{c n 0}+a_{0 n c l} t_{c l} .
$$

Vidutini gamybos laiką ir produkto realizacijos laiką lemia du pagrindiniai veiksniai - rinkos būklè ir technologijos lygis. Pagrindiniai rinkos būklès komponentai, turintys itakos gamybos periodo trukmei, yra gaminančios imonès konkurencingumas ir vartotoju perkamoji galia. Rinkos poreikių tenkinimas gali būti îvertintas rodikliais, apibūdinančiais konkurencingu produktų gamybos apimčiu dinamiką:

$$
I_{g a}=\frac{Q^{p}}{Q^{p a}},
$$

čia $Q^{p}$ - gamybos apimtis periodo pradžioje; $Q^{p a}-$ gamybos apimtis periodo pabaigoje.

Produktų konkurencingumo pasikeitimą pagal kokybès parametrus galima nustatyti taip:

$$
I_{t p}=\frac{I_{t p}^{p}}{I_{t p}^{p a}},
$$

čia $I_{t p}^{p}-$ konkurencingumo rodiklis periodo pradžioje pagal kokybès parametrus; $I_{t p}^{p a}$ - konkurencingumo rodiklis periodo pabaigoje pagal kokybès parametrus.

Produktụ konkurencingumo pasikeitimą pagal išlaidų parametrus galima apskaičiuoti taip:

$$
I_{e p}=\frac{I_{e p}^{p}}{I_{e p}^{p a}},
$$

čia $I_{e p}^{p}$ - konkurencingumo rodiklis periodo pradžioje pagal išlaidu parametrus; $I_{e p}^{p a}$ - konkurencingumo rodiklis pagal išlaidu parametrus periodo pabaigoje.

Apibendrintas konkurencingumo rodiklis bus lygus:

$$
I_{k}=\sqrt{I_{t p} \cdot I_{e p}} .
$$

Naudojant šiuos rodiklius galima apskaičiuoti apibendrintą rinkos poreikių tenkinimo rodiklio pokytį:

$$
I_{r p}=\sqrt{I_{g a} \cdot I_{k}} \text {. }
$$

Gamybos išlaidų pokytis apskaičiuojamas:

$$
I_{g i}=\frac{I_{g i}^{p a}}{I_{g i}^{p}},
$$


čia $I_{g i}^{p a}$ - gamybos išlaidos periodo pradžioje; $I_{g i}^{p}-$ gamybos išlaidos periodo pabaigoje.

Dabar galima apskaičiuoti imonès funkcionavimo efektyvumą:

$$
E=\frac{I_{r p}}{I_{g i}} .
$$

Šis rodiklis charakterizuoja poreikių tenkinimo augimo ir gamybos išlaidu pasikeitimo laipsni. Jei rodiklis didesnis už 1, galima teigti, kad imonès veikla efektyvi, jei mažesnis, - neefektyvi. Apskaičiavus šiuos rodiklius, sudaroma regresinè lygtis laikui $t_{4}$ apskaičiuoti:

$$
\begin{gathered}
t_{4}=f(E), \\
t_{4}=a_{01}+a_{e} e .
\end{gathered}
$$

Tuomet sudaromas stochastinis produkto ciklo modelis. 2 paveiksle toks ciklas pavaizduotas su diskretiniais dydžiais ir nepertraukiamu laiku. Sistemos perejjimas iš vienos būklès ị kitą vyksta atsitiktiniais momentais, kurių negalima iš anksto numatyti, o perèjimo tikimybẻ iš vienos būklès i kitą per laiką $\Delta t$ lygi $\lambda_{i j}$. Taigi naujų produktų gamybos inovacijų fazès laikas, gamyba ir realizacija atitinka Markovo atsitiktini procesą su diskretine būkle ir nepertraukiamu laiku, o realus ivvykių srautas keičiasi pagal Puasono dèsni.

$S_{1}$ - produkto koncepcija; $S_{2}$ - projekto studijos; $S_{3}$ - produkto gimimas, bandomoji serija, pardavimai; $S_{4}$ - produkto realizavimas rinkoje. Be to, sistema gali pereiti i darbų nutraukimo būklę $S_{n}$. Tam turi itakos efektyvesni konkurentų veiksmai, imonès veiklos strateginès krypties pakeitimas, medžiagų tiekimo nutraukimas ir pan. Ciklas, aprašytas Markovo atsitiktiniu procesu su diskretinèmis būklèmis ir nepertraukiamu laiku, apibūdinamas tikimybe $P_{k}(t)$ bei vidutiniu sistemos buvimo kiekvienoje būklèje laiku $t_{k}$.

Matematiškai sistema aprašoma:

$$
\left.\begin{array}{l}
\frac{d P_{1}(t)}{d t}=-\lambda_{12}^{*} P(t) \\
\frac{d P(t)_{i}}{d t}=\lambda_{i-1, i} P_{i-1}(t)-\lambda_{i, i+1}^{*} P(t) \\
\frac{d P_{n}}{d t}=\sum_{i=1}^{4} P_{i}(t) \lambda_{i n}
\end{array}\right\}
$$

čia $\lambda_{i, i+1}^{*}=\lambda_{i, i+1}+\lambda_{i n}, \mathrm{i}=1,2,3$.

Bet kuriuo laiko momentu $t$ tikimybių suma yra lygi 1 [6]:

$$
\sum P_{i}(t)+P_{n}(t)=1
$$

kai $t=0 ; P_{1}(0)=1 ; P_{2}(0)=P_{3}(0)=P_{4}(0)=P_{n}(0)=0$.

Matematiškai imonė aprašoma kaip sistema, pereinanti visus produkto inovacijų fazès ir buvimo rinkoje fazès etapus.

$$
P_{k}(t)=\sum_{j=1}^{k} \frac{\prod_{i=1}^{k} \lambda_{i, i+1}}{\prod_{i=1}^{k}\left(\lambda_{i, i+1}^{*}-\lambda_{j, j+1}^{*}\right)} e^{-\lambda_{j, j+1^{t}}^{*}} \quad k=2,3,
$$

$$
\frac{\prod_{i=1}^{k-1} \lambda_{i, i+1}}{\prod_{i=1}^{k}\left(\lambda_{i, i+1}^{*}-\lambda_{j, j+1}^{*}\right)}=1
$$

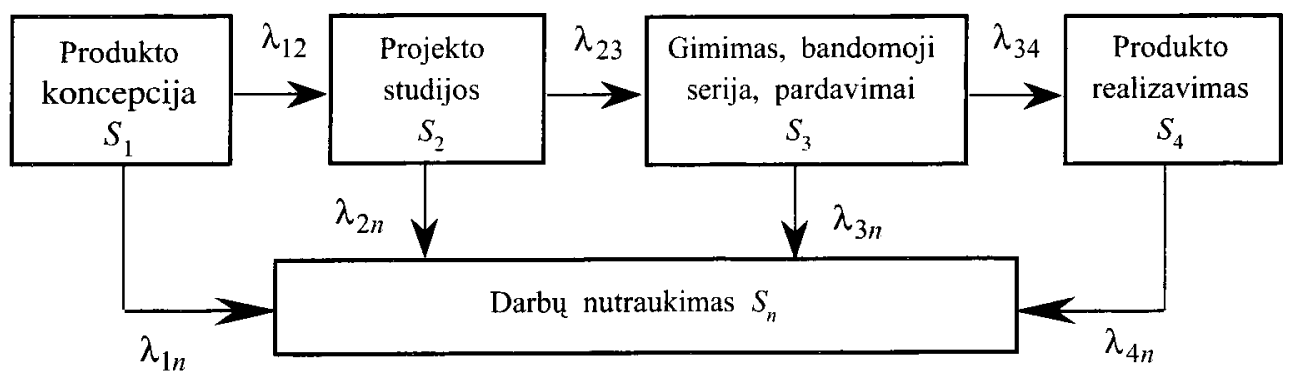

2 pav. Produkto ciklo stochastinis modelis

Fig 2. Stochastic model of product life cycle 
Turint sistemos sprendima, galima nustatyti kiekvienos sistemos būklès vidutini laiką $t_{k}$ :

$$
\overline{t_{k}}=\int_{0}^{\infty} P_{k}(t) d t .
$$

(25) irašę i (27) gauname:

$$
\overline{t_{k}}=\frac{\prod_{i=1}^{k-1} \lambda_{i, i+1}}{\prod_{i=1}^{k-1} \lambda_{i, i+1}^{* *}}, \lambda_{01}=1
$$

Sakykime, $\operatorname{kad} \lambda_{i j}=0(\mathrm{i}=1, \ldots, 4)$, tada gauname:

$$
\lambda_{k, k+1}=\frac{1}{\overline{t_{k}}},
$$

kur $\overline{t_{k}}$ - vidutinis sistemos buvimo $k$-oje būklèje laikas, neatsižvelgiant $i$ tai, kad gali būti nutraukti darbai.

Toks sistemos sprendimas teisingas tuo atveju, kai $\lambda_{i-1, i}^{*} \neq \lambda_{i, i+1}^{*}$.

Tačiau gali pasitaikyti atveju, kai, pavyzdžiui, $\lambda_{12}^{*}=\lambda_{23}^{*}$, tada sistemos sprendimas bus toks:

$$
P_{k}(t)=\sum_{i}^{k} \frac{\prod \lambda_{i, i+1}}{\left(\lambda_{12}^{*}-\lambda_{j, j+1}^{*}\right)^{2} \prod\left(\lambda_{i, i+1}^{*}-\lambda_{j, j+1}^{*}\right)} \times e^{-\lambda_{i, i+1}^{*}}
$$

Tuomet vidutinis laikas $t_{k}$ bus apskaičiuojamas taip:

$$
\begin{gathered}
\overline{t_{k}}=\prod_{i=1}^{k-1} \lambda_{i, i+1}\left[\frac{2}{\lambda_{12}^{* 2} \prod_{i=3}^{k}\left(\lambda_{i, i+1}^{*}-\lambda_{12}^{*}\right)}-\frac{1}{\lambda_{12}^{*}}\right] \times \\
\sum_{j=3}^{k}\left[\frac{1}{\left(\lambda_{j, j+1}^{*}-\lambda_{12}^{*}\right) \prod_{i=3}^{k}\left(\lambda_{i, i+1}^{*}-\lambda_{12}^{*}\right)}\right]+ \\
\sum_{j=3}^{k} \frac{1}{\left(\lambda_{12}^{*}-\lambda_{i, i+1}^{*}\right)^{2} \prod_{i=3}^{k}\left(\lambda_{i, i+1}^{*}-\lambda_{i, i+1}^{*}\right) \lambda_{i, i+1}}
\end{gathered}
$$

Tuo atveju, kai visi $\lambda_{i, i+1}^{*}$ ir sistemos buvimas kiekvienoje būklèje lygūs, t. y. $\lambda_{i, i+1}^{*}=\lambda_{j, j+1}^{*}$, sistemos sprendimas turès išraišką:

$$
P_{k}(t)=\frac{t^{k-1}}{(k-1)} e^{-\lambda_{12}^{*}}+\prod_{i=1}^{k-1} \lambda_{i, i+1} \quad k=1, \ldots, 4,
$$

o vidutinis laikas bus apskaičiuojamas:

$$
\overline{t_{k}}=\frac{k}{\lambda_{12}^{k}} \prod_{i=1}^{k-1} \lambda_{i, i+1}
$$

Remiantis tuo, $\operatorname{kad} T_{i s}=t_{1}+t_{2}+t_{3}$, o $T_{r}=t_{4}$, galima apskaičiuoti koeficientą $K_{0}$ :

$$
K_{0}^{\prime}=\frac{t_{1}+t_{2}+t_{3}}{t_{4}}
$$

Jei $t_{k} \quad(k=1 \div 4)$ išreikštume per $\lambda_{i, i+1}$, tai:

$$
K_{0}^{\prime}=\frac{\lambda_{12}^{*}\left(\lambda_{23}^{*} \lambda_{34}^{*}+2 \lambda_{12} \lambda_{12}^{*}+3 \lambda_{12} \lambda_{23}\right)}{4 \lambda_{12} \lambda_{23} \lambda_{34}} .
$$

Ivertinus (30) ir pažymèjus:

$$
\left.\begin{array}{l}
\lambda_{12}^{*}=\frac{1}{t_{1}^{0}+\Theta_{1}} \\
\lambda_{23}^{*}=\frac{1}{t_{2}^{0}+\Theta_{2}} \\
\lambda_{34}^{*}=\frac{1}{t_{3}^{0}+\Theta_{3}}
\end{array}\right\}
$$

Taip apskaičiuojama:

$$
\begin{gathered}
K_{0}^{\prime}=\frac{t_{3}^{0}}{4\left(t_{1}^{0}+\Theta_{1}\right)} \times \\
\left(\frac{t_{2}^{0} t_{1}^{0}}{\left(t_{2}^{0}+\Theta_{2}\right)\left(t_{3}^{0}+\Theta_{3}\right)}+\frac{2 t_{2}^{0}}{\left(t_{1}^{0}+\Theta_{1}\right)}+3\right) .
\end{gathered}
$$

Jei produktui jeinant i rinką atsiranda konkurentas (arba grupè konkurentų), perèjimo laikas iš būklès $S_{i}$ i darbu nutraukimo būklę suprantamas kaip laikas, būtinas issisavinti ir pradèti realizuoti analogiška, bet tobulesni produktą [7]. Tada:

$$
\left.\begin{array}{l}
\Theta_{1}=2 T_{i s}+t_{4}^{0} \\
\Theta_{2}=\Theta_{1}-t_{1}^{0} \\
\Theta_{3}=\Theta_{2}-t_{2}^{0} \\
\Theta_{4}=\Theta_{3}-t_{3}
\end{array}\right\}
$$

Apskaičiavus dydi $K_{0}^{\prime}$, analogiškai apskaičiuojamas konkuruojančios įmonès $K_{\text {of }}$. Kiekybiškai lyginant dydžius $K_{0}^{\prime}$ ir $K_{o f}$ apskaičiuojamas dydis $\Delta S_{n p}$ :

$$
\Delta S_{n p}=\frac{K_{0}^{\prime}}{K_{o f}}
$$


čia $K_{0}^{\prime}$ - ¿monès $X$ sugebẻjimas taikyti pasirinktą strategiją; $K_{\text {of }}$ - imonès $Y$, kuri yra imonès $X$ didžiausias konkurentas rinkoje, sugebejjimas taikyti strategiją.

Sugebejimas taikyti strategiją galimas, kai:

1) $K_{0}^{\prime}>K_{o f} \rightarrow S_{n p \max }>S_{n p}>1$,

2) $K_{0}^{\prime}<K_{o f} \rightarrow S_{n p \min }<S_{n p}<1$.

Pirmuoju atveju dydžiui $S_{n p}$ artèjant prie $S_{n p \max }$ techninès imonès galimybès yra didesnès. Antruoju atveju - mažesnis lankstumas ir techninis potencialas. Tai reiškia, kad imonès lankstaus vystymosi galimybès nepakankamos ir reikia arba papildomy investiciju, arba koreguoti ìsisavinamų produktų nomenklatūrą.

Norint ivertinti imoniu taikomą strategiją, labai svarbu žinoti jos taikymo ribas. Tuo tikslu apskaičiuojamas koeficientas $K_{F}$, ivertinantis laiką iki produkto gamybos ir realizavimo rinkoje pabaigos, taip pat ir bendrą produkto gamybos ir realizavimo laiką. Jeigu ekspansijos strategijų pabaigą prilyginsime 1, tai:

$$
K_{F}=\frac{F_{k}}{T_{r}}=1-\frac{T_{r}^{\prime}}{T_{r}},
$$

čia $F_{k}$ - laiko dalis iki produkto realizavimo rinkoje pabaigos; $T_{r}^{\prime}$ - produkto realizavimo laikas iki tyrimo pradžios.

Apskaičiavę dydi $K_{F}$, galime apskaičiuoti koeficienta $K_{p}$, ivertinantị faktinius ir tikimybinius dydžius:

$$
K_{p}=\frac{K_{F}}{K_{0}}=\frac{1}{K_{0}}-\frac{T_{r}^{\prime}}{T_{i s}} .
$$

Apskaičiavę dydi $K_{p}$ apskaičiuojami iejjimo i rinką pradžią $T_{r}^{\prime}=0$, tai:

$$
K_{p}=\frac{1}{K_{0}}
$$

Skverbimosi i rinką strategijos pabaiga sutampa su nenuostolingumo tašku, tuomet:

$$
\begin{aligned}
T_{r}^{\prime} & =T_{r} K, \\
\text { todèl } \quad K_{p} & =\frac{(1-K)}{K_{0}},
\end{aligned}
$$

čia $K$ - laiko, reikalingo nenuostolingumo taškui pasiekti, ir bendro gamybos ir realizacijos laiko santykis.

Produkto tobulinimo strategija pradedama taikyti po skverbimosi i rinką strategijos. Todèl produkto taikymo strategijos pabaiga sutampa su jo gyvavimo ciklo viduriu, t. y:

$$
T_{r}^{\prime}=\frac{1}{2} T_{r},
$$

tuomet

$$
K_{p}=\frac{1}{2 K_{0}} \text {. }
$$

\section{Išvados}

1. Imonių pasirinktai ekspansijos strategijai nustatyti reikalingi rodikliai, apibrezžiantys skverbimosi i rin$\mathrm{ka}$, rinkos pletros ir produkto tobulinimo strategiju taikymo ribas.

2. Remiantis Ansoffo produkto-rinkos modeliu ir produkto gyvavimo ciklu, straipsnyje pasiūlytas požiūris i imonei tikslingos strategijos nustatymą.

3. Nustatyto ryšio tarp verslo lygio strategijos ir produkto gyvavimo ciklo pagrindu numatytas ekspansijos strategijų ribų skaičiavimas suteikia galimybę imonei planuoti savo veiklą ateityje.

\section{Literatūra}

1. J. Perace, R. Robinson. Strategic management. Formulation, implementation and control. IRWIN, 1999, p. 229257.

2. I. Ansoff. Corporate strategy. An analytic approach to business policy for growth and expansion. 1979. 23 p.

3. D. Aaker. Developing business strategies. N. Y.: John Wiley \& Sons, Inc., 1992, p. 243-257.

4. Д. Хан. Планирование и контроль концепшии контроллинга. Москва: Финансы и статистика, 1997. 299 с.

5. G. Urban, J. Hauser. Design and marketing of new products. UK: Prentice Hall, 1980, p. 5-6.

6. H. Bierman, Ch. Bonini, W. Hausman. Quantitative analysis for business decisions. IRWIN: Homewood, Illinois, 1986. 624 p.

7. В. Н. Самочкин. Гибкое развитие предприятия. Анализ и планирование. Москва: Дело, 1998. 32 с.

Iteikta $2001 \quad 02 \quad 14$ 


\section{THE EVALUATION OF A COMPANY'S STRATEGY BY THE ANSOFF'S PRODUCT MARKET MATRIX}

\section{R. Ginevičius, R. Auškalnytẻ}

Su m m a ry

The I. Ansoff's theories take a considerable place in the evolution of the strategy research. In our opinion, his works are very important, because there is a clear boundary between the strategy formulation process and the strategy as the result of this process. On the grounds of Ansoff's point of view and his product market matrix, we suggest a methodology for determining the strategy applied by the company. I. Ansoff suggested four types of strategy: penetration, product development, market development and diversification (Fig 1). The diversification strategy is the most risky and distracts the company from its production and marketing. Therefore, the penetration, product development and market development will be evaluated. For the first stage of research the evaluation criteria of expansion strategies are chosen. There is not any common criterion of strategy. For evaluating the market penetration strategy the following criteria are chosen: costs of work, costs of resources, productivity of works, promotion costs on the native market. For evaluating the product development strategy the following criteria are used: number of new products, expenses of R\&D, number of people who work in $R \& D$, number of sold licences and number of bought licences. For market development strategy evaluating the following criteria are applied: number of new geographical markets, promotion costs on new geographical markets, number of people who work in the new markets. These criteria help to gather data for further research. Then the dynamics of criteria changes is calculated according to the formula

$$
I_{j}=\frac{I^{p a}}{I^{p}},
$$

where $I^{p}$ is the meaning of criterion at the beginning of the analyzed period, $I^{p a}$ is the meaning of criterion at its end. This formula helps to calculate the generalized index of expansion strategies according to the formula

$$
\sqrt[n]{\prod_{j=1}^{n} I_{j}}
$$

In the second stage, the priorities of the groups of a company's products are calculated and a group of the product influencing the company's strategy is chosen. On the grounds of sale and export indexes, the product group is attributed to the product life cycle phase. The company's ability to apply strategy is calculated in the third stage of research. Therefore, we have chosen the coefficient $K_{0}$ describing the work of each unit, equipment, technology, employees and changes on the market. The coefficient is calculated by the formula

$$
K_{0}=\frac{T_{i s}}{T_{r}},
$$

where $T_{i s}$ is the time of product innovation, $T_{r}$ is the time of production and realization. The life cycle of product helps to calculate the coefficient $K_{0}$. Therefore, the time parameters of this cycle stages are chosen and calculated by regression analysis. Then the stochastic model of product life cycle is created (Fig 2). By a formula the coefficient is calculated and compared with $K_{0}$ of the most successful company on the market. Besides, the coefficient $K_{0}$ helps to calculate the boundaries of expansion strategy according to the formulas:

$$
\begin{gathered}
K_{p}=\frac{1}{K_{0}}, \\
K_{p}=\frac{(1-K)}{K_{0}}, \\
K_{p}=\frac{1}{2 K_{0}} .
\end{gathered}
$$

In this article we have introduced a methodology of the strategy applied by the company. The methodology proves the fact that there is a connection between the strategy of a company and product life cycle. In addition, this methodology helps to plan the activity of a company in future.

Romualdas GINEVIČIUS. Doctor Habil, Professor. Dean of Business Management Faculty. Vilnius Gediminas Technical University (VGTU), Sauletekio al. 11, LT-2040 Vilnius, Lithuania. E-mail: vstud@vv.vtu.lt

Doctor (1975). Doctor Habil (1997, VGTU). Author of 10 books, monographs, about 150 research articles published in Lithuania and abroad. Member of International Academy of Information, Member of Lithuanian Commitee for Research Prizes. Research interests: market economy, theory of organisations.

Renata AUŠKALNYT⿱亠凶. Doctoral student. Dept of Management. Vilnius Gediminas Technical University (VGTU), Saulètekio al. 11, LT-2040 Vilnius, Lithuania.

Engineer economist (VGTU, 1995), MSc (1997). Research interests: strategic management of enterprises, the business level strategies, the connection between strategy of the enterprise and product life cycle. 